\title{
The Development of Mobile Learning Application using Jigsaw Technique
}

\author{
http://dx.doi.org/10.3991/ijim.v10i3.5268 \\ Dwi Sulisworo, Ishafit, Kartika Firdausy \\ Ahmad Dahlan University, Yogyakarta, Indonesia
}

\begin{abstract}
Teacher ability to arrange learning environmet will affect the student's interest in learning as well in utilizing mobile technology. The purpose of this research is to develop mobile learning using the cooperative learning approach especially the Jigsaw technique. The method of this research is development research using ADDIE model. The application was validated by experts for technical aspects and also students from two different grades, i.e grade VII and grade VIII on physics subject for application acceptance responses. The results showed that both technically and application acceptance were at good levels, meaning that this mobile cooperative learning application can used to enhance student's learning interest.
\end{abstract}

Index Terms-mobile learning, cooperative learning, Jigsaw, education, mobile technology

\section{INTRODUCTION}

Internal and external factors will affect the student success on learning. Internal factors coming from within which drive behavior changing. The example of internal factors are intelligence, talent, skills, interests, motivation, physical condition, and mental. The external factors are conditions beyond the individual that affect learning. External factors include the school environment, family and community, etc.

The results of National Examination of Education Ministry of Indonesia shows that the percentage of student mastery on physics at the level of high school is uneven. In the Indonesian education system, there are several levels of competency. In Yogyakarta Special Province, from 8739 high school students, the number of students achieved competences were between $31.42 \%$ to $86.42 \%$. In addition, the average knowledge acquisition of students is $50.14 \%$. It means there is something to be improved on learning. Based on experience in managing school learning, inequality and the low level of competencies were caused by several factors. One of them is the monotonous learning process where the teacher is less creative and innovative in using a variety of instructional media.

The previous research showed that the cooperative learning tend to be able to improve student's understanding effectively. This learning approach give opportunities to create meaningful, interactive, inspiring, fun, challenging, motivating learning for learners to participate actively. Cooperative learning can be said as a set of teaching strategies designed to promote teamwork teaching and student-student interaction.

On the other hand, almost all schools in the Yogyakarta Special Province currently have internet facilities that can access resources evenly. Many students also have and use their smartphones in daily activities. Observations of students in schools shows that they use smartphones for non-academic activities. This situation is also relatively similar to the general trend of Indonesian society who mainly that uses smart phones for social media activity. Besides, teachers are not encouraged to take advantage of smartphones as a mean of interaction with the students in the learning process.

Some of the advantages of cooperative learning among others, are to teach students to believe the teacher, to train ability to think and to seek information from other sources, and to learn from other students, to encourage students to express ideas verbally and compare with his ideas and to help students to appreciate each other. Seeing these benefits, this research intends to utilize mobile learning with cooperative strategies in enhancing the competence of students in studying physics in high school. This research will develop a learning management system applications with Jigsaw approach using the Android operating system. Furthermore, the application is tested on a certain class to see the response of students in using this application.

\section{LITERATURE REVIEW}

\section{A. Mobile Learning}

Wireless and mobile technology development has grown rapidly in recent years [1][2]. This technology is becoming more and more sophisticated, but at a cheaper price. The use of a smartphone as a mobile learning tool in schools has become controversial among teachers. On one hand, some teachers disagree because it would interfere the learning process in the classroom; on the other hand, some teachers saw a lot of potential that needs to be used in learning [3][4][5]. But, todays educators realize that the digital mobile technology has provided new opportunities for the availability of new and different forms of learning; including the relationship between teachers, learners and learning objects [6]. Given the current technological developments and the latest results of research on learning motivation, appreciation toward media facilitated learning and learning resources varied [5][7]. Learning is much easier and diverse. The use of mobile instruments are proven to encourage student motivation and to support their own learning activities [1][4]. The inability of teachers and, students to adjust with learning environment would make ineffective interactions on learning [6][8].

Mobile learning (m-learning) is part of the electronic learning (e-learning) that provide wider opportunities in mobile and more capabilities for student learning. Thus mlearning can be defined differently from e-learning in term of the mobility of students as learners [4][8]. Learning 
takes place when learners take the advantage of learning opportunities provided by mobile technology [5][9]. The perspectives on mobile learning can be categorized into four, namely techno-centric, with regard to e-learning, tools of formal education, and student-centered learning $[4][10][11][12]$. Nowadays, the current emphasis of technology in schools is ensuring to be used effectively to create new opportunites for learning and to promote student achievement [6][8][9].

\section{B. Cooperative Learning and Jigsaw Technique}

\section{1) Cooperative Learning}

Cooperative learning is an umbrella term for a set of teaching strategies that are designed to teach teamwork and interaction among students [13][14]. Cooperative learning objectives include at least three aspects, which are the result of academic learning, acceptance of diversity, and the development of social skills. This strategy is based on the theory of Vygotsky, which emphasizes social interaction as a mechanism to support cognitive development. Moreover, this method is also supported by learning theory and cognitive information processing theory of learning. The implementation of this learning theory will help students to more easily process the information aquitition, because the encoding process will be supported by the interactions in cooperative learning activities.

Cooperative learning-instructional methods have positive benefits when applied in the classroom. Some benefits include students' belief in the teacher, the ability to think, searching information from various sources and studying with other students, students' encouragement to express ideas verbally and compare it with the other ideas and to help students learn to respect others $[14][15][18]$. The purpose of cooperative learning is different from the conventional group applying competition system, in which individual success oriented to the failure of others. A cooperative learning method with strong support may promote students achievement and a positive attitude towards studies, is very viable option,among others, for teaching science in secondary schools [13][15][16][17].

While the goal of cooperative learning is creating a situation where individual success is determined or influenced by the success of the group [16][17][18]. By definition, cooperative learning model is a model of learning in practice emphasizing the use of groups of students. The principle that should be upheld in connection with cooperative groups is that every student in a group has heterogeneous ability level (high, medium, low) and if necessary they must come from different races, cultures, different ethnic groups and consider gender equality. Cooperative learning model is based on cooperation while solving the problems of learning. This learning model is different from collaborative learning, characterized by the presence of a learning task structure, the structure of the learning objectives and reward structures [13][19].

\section{2) Jigsaw Technique}

Jigsaw is one of many cooperative learning techniques. The purpose of this technique is to increase the students' sense of responsibility for their own learning and also to learn from other members of their group [16][18]. They were asked to study the material that will be the responsibility, because in addition to himself, they must also teach that material to other members of their group. Jigsaw technique is a simulated setting of scientists of scientific community [13]. Using this technique, students will be able to understand any phenomenon requiring research activity.

In Jigsaw learning, the dependence among students is very high. Basically, each student will be a member of two groups, namely (1) the group home and (2) the expert group. The home group was formed by members of the heterogeneous [13][17]. In this group home, they will share the task of the learning topics. After all members of the home group have completed each task, they would leave the home group to form an expert group. The expert group is a group formed from members of the group who has the same task of the studied topic (based on their agreement in the home group). After studying the topic in their expert group, they will be back to their home groups and teach each topic as their responsibility to the rest of the group in turn.

\section{METHODS}

This research is the developmental research which the final result is a Learning Management System with mobile technology using Jigsaw technique as a variant of cooperative learning. This application was developed using ADDIE model (Analysis, Design, Development, Implementation, Evaluation). After the programming tests on technical side, it would be tested for the users' acceptance i.e high school students. The learning implementation involved teachers and students at certain high schools on physics subjects.

The facillites of this mobile learning system include registration, user management, and subject management. The learning procedures were developed in accordance with Jigsaw method, namely:

a) Students in the class are divided into groups.

b) Students are asked to work on pre-test problems. The pre-test score will be the basis for the teacher to determine group division, which are called as Study Groups.

c) Study groups were determined manually by the teacher by considering the heterogeneity, gender and pre-test scores;

d) The teacher provides topics to be studied (4-5 topics), which will be the basis of the number of Expert Groups;

e) Students in a study group are divided into sub-groups which will discuss each topic in a discussion forum and choose an Expert Group;

f) An Expert Group discussion forum consists of students from different Study Group to discuss a topic, give questions one another, and do exercises that have been prepared by the teacher;

g) The students then return to their previous study group, explain or share material that has been studied on the expert group by writing explanation of concepts through different discussion forums according to the topics. Other members of the study group ask questions, while the expert answers. After the completion of sharing process, the students are asked to do exercises on the topics.

h) At the individual test stage, the students work on a test which covers all the topics that have been provided by the teacher. 
The mobile learning system was built for three types of users, namely administrators, teachers, and students. The facilities provided for the teachers are for management of the subjects, e.g. uploading material, devising tests and evaluations; analyze test results, downloading the results of student work, creating discussion forums, as well as creating home groups and expert groups. The students were allowed to view and to download the material, to do tests, and to participate in discussion forums. Development of this system was done using Moodle version 2.8, Sublime Text 3 OS Linux Fedora 22, 2 Apache server, MySQL 5:35, Inkscape (for design). The system can be accessed via http://mlearning.pf.uad.ac.id/.

\section{RESUlt AND DisCUSSION}

\section{A. System Interface}

Below is some description related to the interface of the mobile application.

\section{1) Login Page}

This page is an initial view through http://mlearning.pf. uad.ac.id mobile learning system. Login page view as in Figure 1 will appear after the user presses the Login button in order to enter into the system.

\section{2) Learning Material Page}

After the user successfully logged in to be able to see material that has been uploaded to the system. Example of the display is shown in Figure 2. On this page, teachers can manage (create new, update, delete) the material according to the needs of learning.

\section{3) Practice/ Evaluation Page}

Figure 3 shows the facilities by which teachers can manage test or evaluation. On the student side, results from this menu will be in the form of questions for practices and evaluation of certain learning outcomes.

\section{4) Pretest Page}

Before students begin to learn certain material, students are directed to do pretest. Results of this pretest will be useful for teachers to form the home group. On this page, students solve the problems that had been prepared by the teacher. Examples of this page is shown in Figure 4.

\section{5) Achievement Report Page}

After each student completed the work related to the provided problems at pretest, learning activities, and evaluation of learning, this application will classify the results on the report page. Through this page, the teacher can see the recapitulation of the activities score of all the students involved in learning. The example of this report is shown in Figure 5.

\section{6) Grouping Page}

This page is the most important page in this learning activity using Jigsaw. Through this page the teacher can create a home group and an expert group. Teacher can consider pretest results for grouping the students. The example of this page is shown in Figure 6.

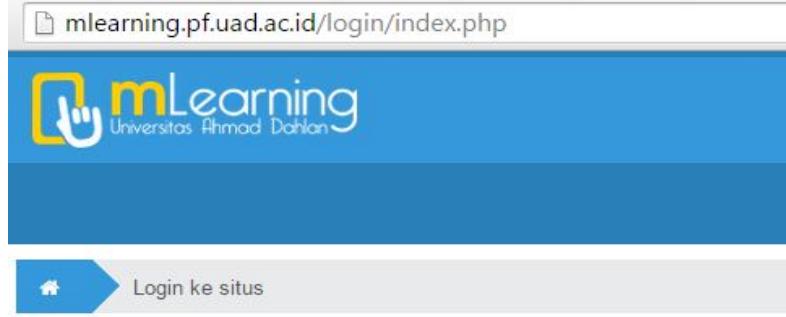

\section{Login}

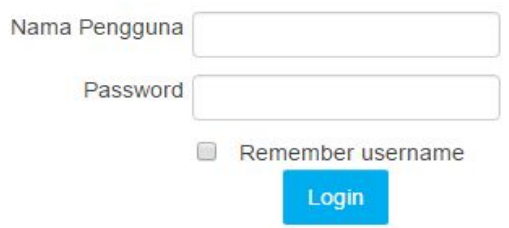

Lupa nama pengguna dan password Anda?

Figure 1. Login Page

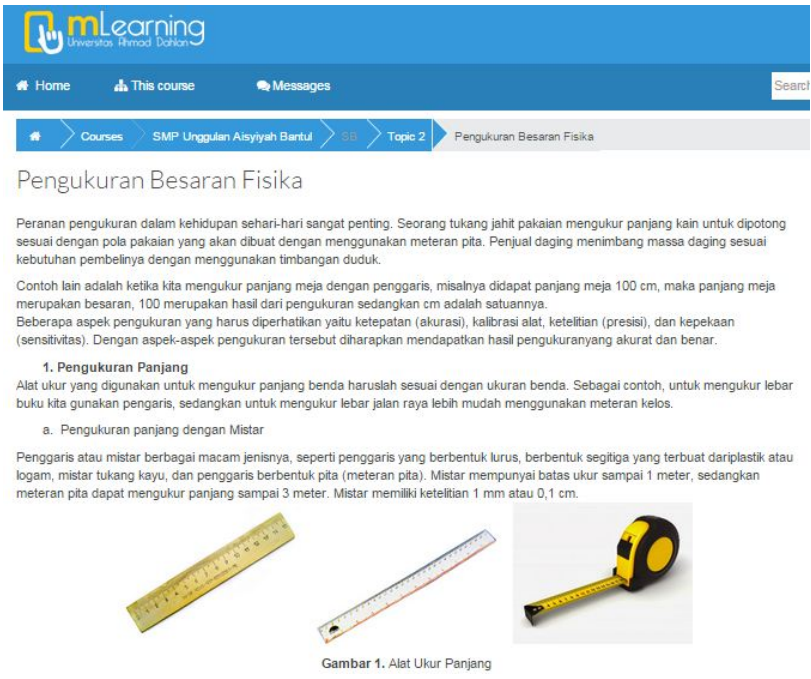

Figure 2. Learning Material Page

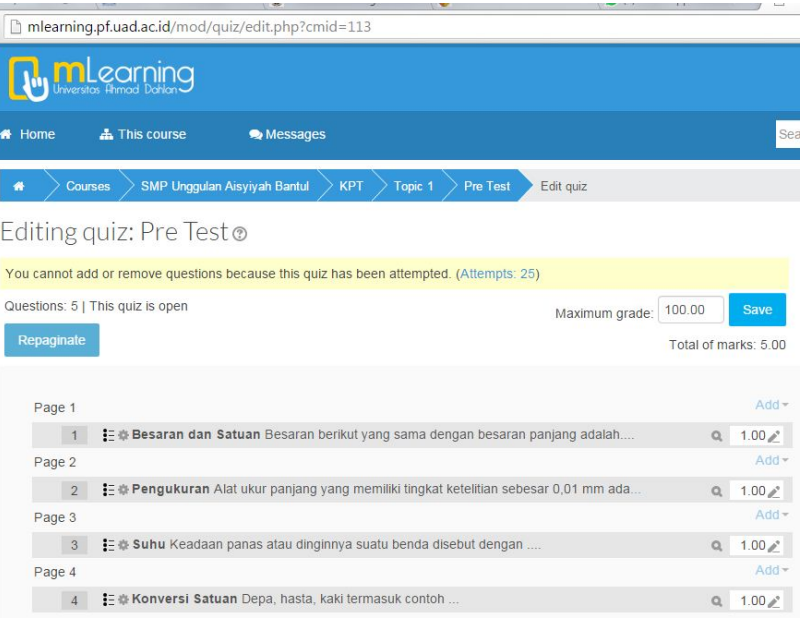

Figure 3. Practice management page 
PAPER

The DeVelopment of Mobile LEARning APPLiCATION USING JigSAW TECHNiQUE

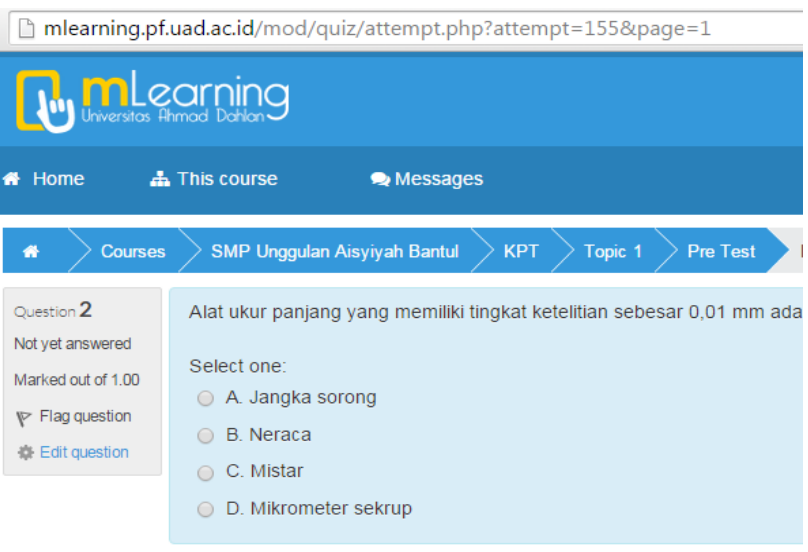

Next

Figure 4. Pretest page

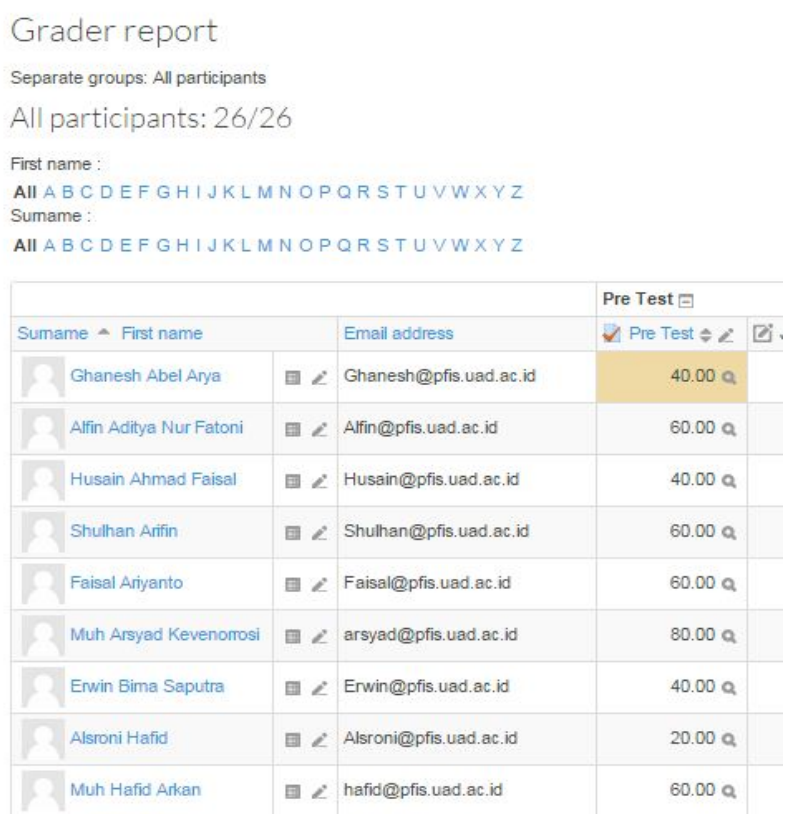

Figure 5. Achievement report page

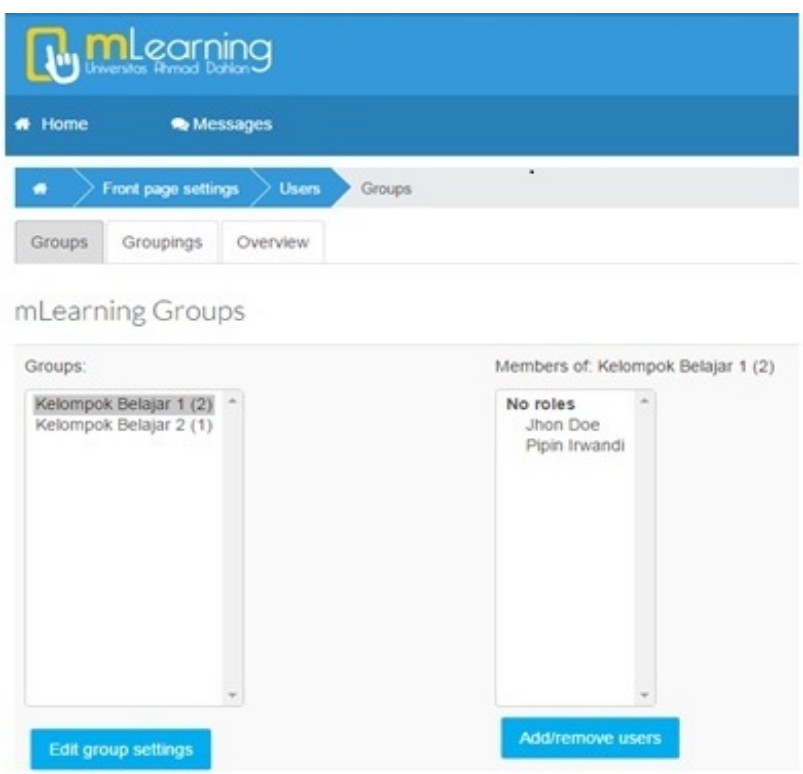

Figure 6. Grouping page

\section{B. Evaluation of Mobile Application}

\section{1) Alpha test and System Validity}

An alpha test was done twice. The first alpha test gave the following results for improving: access/ loading was still too long, so it was not effective for many users; time to access was still very slow, even server was down and completely inaccessible; the accessibility was still difficult; some features was not functioning properly.

Second alpha test gave the result that the application system was better, the access was not slow anymore when accessed many users; the system could be applied directly into the learning; the features provided in principle had been proper already; and time to access had been smooth; and features could be used well.

\section{2) Expert judgement}

After the system was ready, an expert was invited to decide the feasibility of mobile learning application. The system was tested and the content and learning media aspects were assessed. Some aspects to be considered were instructional design (14 items), lesson content (5 items), flexibility of use (3 items), and technical quality (4 items). This quesionaire used Likert scale out of 4. From two experts judgment on the feasibility test, the result is was shown on table I below.

TABLE I.

RESULT OF THE FEASIBILITY JUDGEMENT FROM EXPERTS

\begin{tabular}{|c|c|c|c|c|c|c|}
\hline \multirow{2}{*}{ No } & \multirow{2}{*}{ Aspects } & \multirow{2}{*}{$\begin{array}{c}\text { Max } \\
\text { Score }\end{array}$} & \multicolumn{2}{|c|}{ Score } & \multirow{2}{*}{ Avg } & \multirow{2}{*}{$\%$} \\
\hline & & & $\operatorname{Exp} I$ & $\operatorname{Exp} I I$ & & \\
\hline 1 & Instructional Design & 56 & 49 & 51 & 50 & 89 \\
\hline 2 & Lesson Contents & 20 & 18 & 19 & 18.5 & 93 \\
\hline 3 & Flexibility & 12 & 11 & 10 & 10.5 & 88 \\
\hline 4 & Technical quality & 16 & 14 & 15 & 14.5 & 91 \\
\hline \multicolumn{2}{|c|}{ Avarage of total score } & & & & & 90 \\
\hline
\end{tabular}

Figure 7 below shows the result of the faesibility of the mobile learning application. In general, it can be concluded that the application was good.

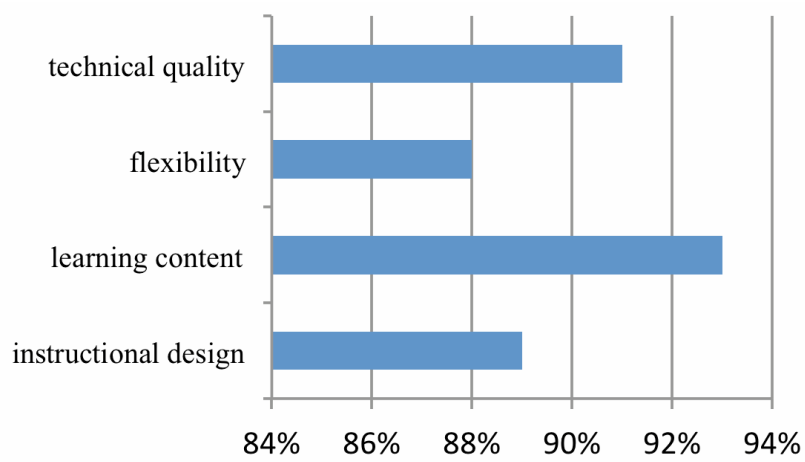

Figure 7. Feasibility judgment from the experts

\section{3) Students's Response}

For testing the students' responses, two different grade of higher students were involved i.e grade VII and VIII. They also came from different school. The test was conducted at the different time of implementation. At the first, this group would be assigned as home groups and expert groups. The grouping can be described in figure 8 .

The number of respondent for the implementation test of this mobile learning was shown on table II below. 
Furthermore, students would carry out learning by using this application under teacher coordination. After their learning activities, students gave their response through provided questionnaire. Number of items is 10 using Likert scale out of 4 .

Table III shows the recapitulation of students' response. From this table, the overall frasibility based on student response can be analyzed.

From table III, the student responses show that the overall feasibility of the application is very good as mention in figure 9 below. In general it can be said that from the student side, this application was feasible to use.

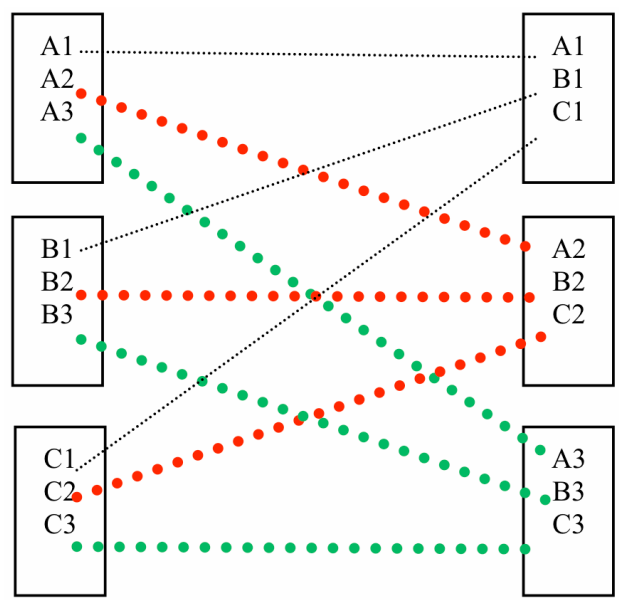

Home group

Expert

Figure 8. Grouping technique for Jigsaw

TABLE II.

STUDENT RESPONDENT STRUCTURE

\begin{tabular}{ccc}
\hline Grade & VII & VIII \\
\hline No. of Student & 20 & 32 \\
\hline male & 13 & 14 \\
\hline female & 7 & 18 \\
\hline $\begin{array}{c}\text { No. of home } \\
\text { group }\end{array}$ & 2 & 4 \\
\hline $\begin{array}{c}\text { No. of expert } \\
\text { group }\end{array}$ & 3 & 4 \\
\hline $\begin{array}{c}\text { Learning } \\
\text { Subject }\end{array}$ & $\begin{array}{l}\text { Units of } \\
\text { Measurement } \\
\text { Topics: Basic unit of } \\
\text { length, Basic unit of } \\
\text { mass, Basic unit of time, } \\
\text { Basic unit of } \\
\text { temperature, Derivatives } \\
\text { Unit: volume, densityy, } \\
\text { and speed. }\end{array}$ \\
\hline
\end{tabular}

TABLE III

STUDENT RESPONSE RECAPITULATION

\begin{tabular}{llcccc}
\hline & Feasibility aspects & $\mathbf{\%}$ & Items & Score & Max \\
\hline 1 & Acceptance & 91 & $1,3,7$ & 10.88 & 12 \\
2 & Interest & 90 & $2,4,6$ & 10.81 & 12 \\
3 & Easiness & 87 & $5,8,9,10$ & 13.94 & 16 \\
\hline
\end{tabular}

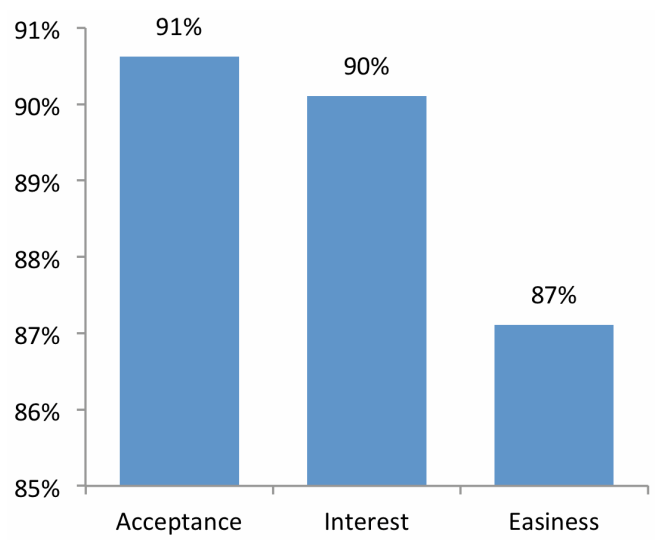

Figure 9. Average response of students to the application

\section{SUMMARY}

This article focuses on learning innovation by combining Jigsaw techniques in cooperative learning and mobile technology. This system was developed to enable teachers to organize more effective learning. Students with smartphones are also more challenged to use smartphones better. This mobile application has been developed with simple features but adequate for good learning. The interface was made to meet the needs of users as well as have various types of media such as text, images, animation and video. Application can be accessed at http://mlearning.pf.uad.ac.id.

\section{REFERENCES}

[1] Alqahtani, M., \& Mohammad, H. (2015). Mobile Applications' Impact on Student Performance and Satisfaction. TOJET: The Turkish Online Journal of Educational Technology, Vol. 14 Issue $4,102-112$.

[2] Sulisworo, D. (2014). Concetual Model Identification of Personal Learning Environment. Innovation and Development in Teaching and Learning (hal. 37-41). Perak, Malaysia: UMM.

[3] Sulisworo, D. (2013). The Paradox on IT Literacy and Science's Learning Achievement in Secondary School. Internasional Journal of Evaluation and Research in Education, Vol 2 No. 4, 149-152. http://dx.doi.org/10.11591/ijere.v2i4.2732

[4] Tal, H. M., \& Gross, M. (2014). Teaching Sustainability via Smartphone-Enhanced Experiential Learning in a Botanical Garden. International Journal of Interactive Mobile Technology, Vol. 8, Issue 1, 10-15.

[5] Mohammad, H., Fayyoumi, A., \& AlShathry, O. (2015). Do We Have to Prohibit the Use of Mobile Phones in Classrooms? International Journal of Interactive Mobile Technology, Vol. 9, Issue 2 , 54-57. http://dx.doi.org/10.3991/ijim.v9i2.4394

[6] Babiker, M. E. (2015). For Effective Use of Multimedia in Education, Teachers Must Develop their Own Educational Multimedia Applications. TOJET: The Turkish Online Journal of Educational Technology, Vol. 14 Issue 4, 62-68.

[7] Kirmizi, Ö. (2014). A Study on the Predictors of Success and Satisfaction in an Online Higher Education Program in Turkey. International Journal of Education,Vol. 6, No. 4, 26-45. http://dx.doi.org/10.5296/ije.v6i4.6322

[8] Thinley, P., Reye, J., \& Geva, S. (2014). Tablets (iPad) for MLearning in the Context of Social Constructivism to Institute an Effective Learning Environment. International Journal of Interactive Mobile Technology; Vol. 8, Issue 1, 16-20. http://dx.doi.org/10.3991/ijim.v8i1.3452

[9] Ebrahim, H. S., Ezzadeen, K., \& A.K, A. (2015). Acquiring Knowledge through Mobile Applications. International Journal of Interactive Mobile Technology, Vol. 9, Issue 3, 71-74.

[10] Crampton, A., Ragusa, A. T., \& Cavanagh, H. (2012). Crossdiscipline investigation of the relationship between academic performance and online resource access by distance education 
students. Research in Learning Technology Volume 20 , 1-13. http://dx.doi.org/10.3402/rlt.v20i0.14430

[11] Kukulska-Hulme, A. (2007). Mobile Usability in Educational Contexts: What have we learnt? International Review of Research in Open and Distance Learning, Volume 8, Number 2, 1-12.

[12] Chen, C.-H., Chen, S.-H., Hwang, G.-J., \& Yang, T.-C. (2010). Factors influencing teachers' adoption of a ubiquitous technology application in supporting teacher performance. International Journal of Mobile Learning and Organisation, Volume 4, Number 1, 39-54. http://dx.doi.org/10.1504/IJMLO.2010.029953

[13] Mehta, S., \& Kulshrestha, A. K. (2014). Implementation of Cooperative Learning in Science: A Developmental-cumExperimental Study. Education Research International, Vol. 2014, 1-7. http://dx.doi.org/10.1155/2014/431542

[14] Gillies, R. M., \& Boyle, M. (2010). Teachers' reflections on cooperative learning: Issues of implementation. Teaching and Teacher Education, Vol. 26 , 933-940. http://dx.doi.org/10.1016/ j.tate. 2009.10.034

[15] Ajaja, O. P., \& Eravwoke, O. U. (2010). Effects of Cooperative Learning Strategy on Junior Secondary School Students Achievement in Integrated Science. Electronic Journal of Science Education Vol. 14, No. 1, 1-18.

[16] Tsay, M., \& Brady, M. (2010). A case study of cooperative learning and communication pedagogy: Does working in teams make a difference? Journal of the Scholarship of Teaching and Learning, Vol. 10 No. 2 , 78-89.

[17] Sulisworo, D., \& Suryani, F. (2014). The Effect of Cooperative Learning, Motivation and Information Technology Literacy to
Achievement. International Journal of Learning \& Development, Vol. 4, No. 2 , 58-64. http://dx.doi.org/10.5296/ijld.v4i2.4908

[18] Zakaria, E., Solfitri, T., Daud, Y., \& Abidin, Z. Z. (2013). Effect of Cooperative Learning on Secondary School Students' Mathematics Achievement. Creative Education, Vol.4 No.2 , 98100. http://dx.doi.org/10.4236/ce.2013.42014

[19] Davidson, N., Major, C. H., \& Michaelsen, L. K. (2014). Smallgroup learning in higher education-cooperative, collaborative, problem-based, and team-based learning: An introduction by the guest editors. Journal on Excellence in College Teaching, Vol 25 No (3\&4), 1-6.

\section{AUTHORS}

Dwi Sulisworo has expertise on educational technology and is a scholar at Physics Education Department of Ahmad Dahlan University, Indonesia (e-mail: sulisworo@gmail.com)

Ishafit has expertise on physics education and is a scholar at Physics Education Department of Ahmad Dahlan University, Indonesia (ishafit@pfis.uad.ac.id)

Kartika Firdausy has expertise on Informatics and is a scholar at Electrical Engineering of Ahmad Dahlan University, Indonesia (e-mail: kartika@ee.uad.ac.id)

Submitted 15 November 2015. Published as resubmitted by the authors 23 January 2016. 